\section{Segregation of Scab Resistance in Three Apple Populations: Molecular Marker and Phenotypic Analyses}

\author{
David Shupert, ${ }^{1}$ Aaron P. Smith, ${ }^{2}$ Jules Janick, ${ }^{3}$ Peter B. Goldsbrough, ${ }^{3}$ \\ and Peter M. Hirst ${ }^{4}$ \\ Department of Horticulture and Landscape Architecture, Purdue University, \\ West Lafayette, IN 47907
}

\begin{abstract}
The codominant PCR marker AL07-SCAR closely linked to the $V_{f}$ gene for scab resistance was used to genotype seedlings in three apple populations in which each parent ('GoldRush', 'Enterprise', 'Pristine', and CQR10T17) was resistant to apple scab. The marker was used to predict the genotype at the $V_{f}$ locus. Each parent was heterozygous. In two populations (CQR10T17 x 'GoldRush'and 'Pristine' $x$ 'GoldRush') seedlings segregated 1:2:1 for fragments associated with $V_{f} V_{f} V_{f} v_{f} v_{f} v_{f}$ as predicted by Mendelian segregation. However, in another population ('GoldRush' $x$ 'Enterprise') the ratio was 1.5:1:1.5, suggesting some type of selection against heterozygotes. Fruiting seedlings were rated for the presence of fruit scab. No scab was observed on seedlings homozygous for the PCR marker linked to $V$, a small amount of scab was observed on one heterozygous seedling out of 35 , and 22 of 26 seedlings that were homozygous recessive, had fruit scab.
\end{abstract}

The apple scab disease, caused by the fungus Venturiainaequalis, is one of the most serious diseases affecting apples worldwide. This pathogen infects leaves thereby reducing photosynthetic capacity and also attacks fruit causing cosmetic blemishes. A number of apple cultivars have been bred that are resistant to scab, most of them owing their resistance to the presence of the $V$ gene, originally found in the crab apple Malus floribunda 821 (Janick et al., 1996).

Breeding fruit trees that have superior fruit quality and horticultural characteristics, in addition to disease resistance traits, is an enduring challenge. The use of genetic markers, however, can speed up the process of selecting for a specific trait, provided that suitable markers tightly linked to genes controlling that trait have been identified.

Many genetic markers have been identified that are linked to the $V_{f}$ gene. These include isozymes (Manganris et al., 1994), RAPDs (Gianfrancheschi et al., 1996, Tartarini, 1996) andAFLPs (Xu and Korban, 2000). High resolution mapping has ordered these markers relative to the $V_{f}$ locus and several are very tightly linked (Xu and Korban, 2000). Some of the RAPD and AFLP markers have been converted into more robust PCR markers (Tartarini et al., 1999, Xu et al., 2001). One of these, AL07-SCAR, lies about $0.2 \mathrm{cM}$ from the $V_{f}$ locus (Xu and Korban, 2000). This marker has the advantage of being codominant, i.e. it can distinguish between individuals that are heterozygous or homozygous for either allele at this locus. We have used the

Received for publication 22 Sept. 2003. Accepted for publication 26 Feb. 2004. Journal paper 17198 of the Purdue University Agricultural Research Program. ${ }^{1}$ Undergraduate student. Current address: Department of Horticultural Sciences, Texas A\&M University, College Station, TX 77843.

${ }^{2}$ Graduate student. Current address: Department of Genetics, University of Georgia, Athens, GA 30602. ${ }^{3}$ Professor.

${ }^{4}$ Associate professor. To whom reprint requests should be addressed; email hirst@purdue.edu.
AL07-SCAR marker to predict the inheritance of the $V_{f}$ gene in three apple populations derived from scab resistant parents and that share the scab resistant cultivar 'Goldrush' as a common parent. Molecular genetic analysis was compared with field evaluation of scab resistance

The objectives of this study were to determine the inheritance of $V_{f}$ and whether the molecular marker genotype was a good predictor of scab infection in field conditions. Furthermore, the identification of homozygous $V_{f} V_{f}$ genotypes would be valuable for use as parents to produce seedling populations in which all individuals were scab resistant.

\section{Materials and Methods}

Three populations were generated by controlled hybridizations in Spring 1996, all made with scab resistant parents. These populations were A) 'GoldRush' x 'Enterprise', B) CQR10T17 x 'GoldRush', and C) 'Pristine' $x$ 'GoldRush' (Table 1). These parents were all selections from the PRI (Purdue-Rutgersal., 1992). Based on parentage (resistant $x$ susceptible), 'GoldRush' and 'Pristine' were assumed to be heterozygous for $V_{f}$ (Crosby et al., 1994b, Janick et al., 1995), whereas the genotypes of 'Enterprise' and CQR10T17 were unknown since both parents were heterozygous for scab resistance and so they could be either homozygous or heterozygous for $V$ (Crosby, 1994a).

Seeds from these hybridizations were germi-

Table 1. Segregation of the AL07-SCAR marker in seedlings of three apple populations. All parents were heterozygous (466/724). The 466-bp fragment is linked to $V_{f}$ whereas the 724-bp fragment is linked to $v_{f}$.

\begin{tabular}{lcccc}
\hline Population & $466 / 466$ & $466 / 724$ & $724 / 724$ & Chi square \\
\hline A) 'GoldRush' x 'Enterprise' & 37 & 23 & 36 & $26.07^{* *}$ \\
B) CQR10T17 x 'GoldRush' & 28 & 51 & 27 & 0.17 \\
C) 'Pristine' x 'GoldRush' & 23 & 52 & 24 & 0.27 \\
\hline
\end{tabular}

***ignificantly different from $1: 2: 1$ ratio at $p=0.01$. were used containing $25 \mathrm{ng}$ of genomic DNA, $0.1 \%$ Triton X-100, $2 \mathrm{~mm} \mathrm{MgCl}_{2}, 250 \mathrm{~nm}$ of each primer, $200 \mu \mathrm{M}$ dNTPs, de-ionized water, and $1 \mathrm{U}$ Taq polymerase (Promega, Madison, Wis.). The primers used to amplify the AL07SCAR marker were: forward primer 5'-TGGAAGAGAGATCCAGAAAGTG-3' and reverse primer 5'-CATCCCTCCACAAATGCC-3' (Tartarini et al., 1999). The primers were purchased from MWG Biotech (High Point, N.C.). The amplification conditions for the ALO7 marker were as follows: $3 \mathrm{~min}$ at $95{ }^{\circ} \mathrm{C}$, followed by 40 cycles of $30 \mathrm{sec}$ at 95 ${ }^{\circ} \mathrm{C}, 1 \mathrm{~min}$ at $60^{\circ} \mathrm{C}, 2 \mathrm{~min}$ at $72{ }^{\circ} \mathrm{C}$, followed by $10 \mathrm{~min}$ at $72^{\circ} \mathrm{C}$. The samples were stored at $4{ }^{\circ} \mathrm{C}$. Five microliters of each PCR was analyzed by agarose gel electrophoresis. The PCR products were separated in $1 \%$ agarose gels at $130 \mathrm{v}$ for $45 \mathrm{~min}$ using a Tris-acetate buffer. The DNA fragments were stained with ethidium bromide, visualized under UV light and photographed. A 100-bp ladder of DNA fragments (BioRad, Hercules, Calif.) was used as a size standard.

The presence of scab was rated on the same trees used for the PCR study during the summer of 2002. Trees received no fungicide applications. Scab infections were more obvious on fruit than leaves, therefore fruit scab was assessed and rated as 0 (no visible scab), 1 ( $\leq 2$ lesions/tree), 2 (3 to 5 lesions/tree), or 3 ( $>5$ lesions/tree). Only those trees bearing fruit could be assessed for fruit scab and scored for resistance or susceptibility. The proportion of trees bearing fruit was $32 \%, 21 \%$, and $30 \%$ for populations $\mathrm{A}, \mathrm{B}$, and $\mathrm{C}$, respectively. in these populations. Illinois) apple breeding program (Crosby et

nated and grown initially in a greenhouse before they were transferred to the field. Populations A, B, and C consisted of 410, 337, and 578 seedlings, respectively. Approximately the first 100 trees from each population were used in this study. Within each population, trees were planted randomly down the row, so the 100 trees selected should have provided a reasonable representation of each population without any obvious bias in sampling. When trees were in their fifth growing season, leaf samples were collected from each plant as well as from the four parents. Samples were also collected from M. floribunda 821 (scab resistant) and 'Gala' (scab susceptible).

During Fall 2001 five leaf discs were collected from each tree using a $7 \mathrm{~mm}$ diameter hole punch and placed into $1.5 \mathrm{ml}$ microfuge tubes. Fresh leaf tissues were placed in liquid nitrogen and then stored in $\mathrm{a}-20^{\circ} \mathrm{C}$ freezer until DNA extractions were performed. Genomic DNA was extracted from frozen leaf discs as described by Doyle and Doyle (1990).

PCR amplifications were performed on the extracted DNA as described by Tartarini et al., (1999), except that $10-\mu \mathrm{L}$ reaction volumes

HortScience Vol. 39(6) October 2004 


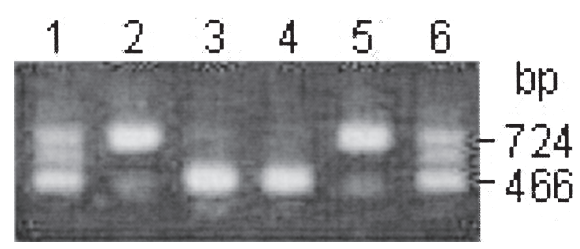

Fig. 1. PCR amplification pattern of AL07-SCAR marker to apple DNA on an agarose gel stained with ethidium bromide. Lanes are $1=$ CQR10T17 (466/724); 2 = 'Gala' (724/724); $3=$ M. floribunda 821 (466/466); $4=466 / 466$ seedling; 5 $=724 / 724$ seeding; $6=466 / 724$ seedling. The 466-bp fragment is linked to $V_{f}$ whereas the 724-bp fragment is linked to $v_{f}$.

\section{Results and Discussion}

The PCR primers for AL07-SCAR amplified a fragment of $466 \mathrm{bp}$ using template DNA from the scab resistant $M$. floribunda 821 (Fig. 1, lane 3). DNA from the susceptible cultivar 'Gala' produced a fragment of 724 bp (Fig. 1, lane 2). These results are in agreement with those presented by Tartarini et al., (1999) who showed that the 466 bp PCR product was linked to the $V$ gene whereas the 724-bp fragment was associated with the allele for susceptibility to scab. Because this marker is co-dominant, PCR amplification of DNA from trees that are heterozygous at this locus should produce both fragments. Two examples of this are shown in Fig. 1. DNA from both CQR10T17 and a tree from one of the segregating populations analyzed in this study (lanes $\mathrm{C}$ and 5 , respectively) resulted in amplification of both the 724- and 466-bp fragments, indicating these plants are heterozygous.

In addition to these two fragments a third PCR product, between $724 \mathrm{bp}$ and $466 \mathrm{bp}$, was observed in samples from heterozygous individuals. This intermediate PCR product amplified from heterozygous plants has not been reported previously in apple and was very reproducible under the conditions used in these experiments. This fragment may have been a heteroduplex between the 724-and 466-bp fragments, as has been found in cranberry (Novy and Vorsa, 1996). The nature of this fragment has not been investigated further.

All four cultivars used as parents of the populations examined in this study ('GoldRush', 'Pristine', 'Enterprise' and CQR10T17) produced the three-band pattern, indicating each was heterozygous at the AL07-SCAR marker, close to the $V_{f}$ locus. Since the parents for all three populations appeared to be heterozygous (Table 1), the progeny would be expected to segregate at the $V_{f}$ locus with a ratio of 1:2:1 $V_{f} V_{f} \cdot V_{f} v_{f} \cdot v_{f} v_{f}$, resulting in a phenotypic ratio of 3 resistant : 1 susceptible. Approximately 100 trees from each of the three populations were genotyped by PCR with marker AL07-SCAR. Populations $\mathrm{B}$ and $\mathrm{C}$ segregated with the expected ratios, with $74.5 \%$ and $75.8 \%$ of the seedlings, respectively, containing at least one copy of the marker allele linked to the $V_{f}$ gene and expected to be resistant to apple scab (Table 1). However, Population A ('GoldRush' $x$ 'Enterprise') did not give the expected segregation ratio. The observed ratio was close to 1.5:1:1.5, indicating a pronounced under-representation of the heterozygous class. The most likely explanation for the observed segregation ratio is that there has been some inadvertent selection against heterozygous plants. No segregation for dwarfs or lethals was observed in this population. Additional genotypic analysis with other molecular markers may be able to provide an answer to this question. Interestingly, the reciprocal cross ('Enterprise' $x$ 'GoldRush') did not set fruit and suggests either some type of incompatibility (unlikely in a gametophytic system) or an adverse response to emasculation (Janick, unpubl.).

The frequency of recombination between AL07-SCAR and $V_{f}$ has been estimated to be between $0.2 \%$ and $2.0 \%$ in various studies (Tartarini et al., 1999, Xu and Korban, 2000).

Because the AL07-SCAR marker is tightly linked to the $V_{f}$ gene, it should be possible to use this marker to predict the scab resistance phenotype of an individual tree with some confidence. Any plant carrying at least one copy of the AL07-SCAR allele that gives the $466 \mathrm{bp}$ product would be expected to be resistant to scab. There is some evidence to suggest that trees homozygous for $V_{f}$ are more resistant than heterozygous trees (Sansavini etal., 2002). Trees that had been genotyped from the three populations were assayed for fruit scab. Over all three populations, none of the seedlings homozygous for the 466-bp PCR product (linked to $V_{f} V_{f}$ ) exhibited fruit scab while a single heterozygous (466/724) tree out of 35 showed a small amount of scab (Table 2). Susceptibility to scab in this one tree may have resulted from a recombination between the $V_{f}$ locus and the marker. Of the trees that were homozygous for the 724-bp fragment, scab was evident on 22 of the seedlings. Four trees were scab-free and these were likely to be escapes, i.e., susceptible but not showing symptoms of disease, since we observed the effects of natural field infection and did not use controlled inoculations of the pathogen. It is interesting to note that even in Population A, where we observed non-Mendelian segregation ratios for the PCR marker, the marker genotype was still an excellent predictor of scab resistance. Additional data will be required to determine if trees that are homozygous for the 466-bp product demonstrate a higher degree of scab resistance than those that are heterozygous. Overall, these results indicate that the AL07-SCAR marker genotype of trees can be used as a useful and reliable tool to predict scab resistance in these and other apple populations.

\section{Literature Cited}

Crosby, J.A., J. Janick, P.C. Pecknold, S.S. Korban, P. A. O'Conner, S.M. Reis, J. Goffreda, and A. Voordeckers. 1992. Breeding apples for scab resistance: 1945-1990. Fruit Var. J. 46:145-166.

Crosby, J.A., J. Janick, P.C. Pecknold, J.C Goffreda, and S.S. Korban. 1994a. 'Enterprise' apple. HortScience 29:825-826.

Crosby, J.A., J. Janick, P.C. Pecknold, J.C Goffreda, and S.S. Korban. 1994b. 'GoldRush' apple. HortScience 29:827-828.

Doyle, J.J. and J.L. Doyle. 1990. Isolation of plant DNA from fresh tissue. Focus 12:13-15.

Gianfranceschi, L., B. Koller, N. Seglias, M. Kellerhals, and C. Gessler. 1996. Molecular selection in apple for resistance to scab caused by Venturia inaequalis. Theor. Appl. Genet. 93:199-204.

Janick, J., J.A. Crosby, P.C. Pecknold, J.C Goffreda, and S.S. Korban. 1995. 'Co-op 32' (Pristine ${ }^{\mathrm{TM}}$ ) apple. HortScience 30:1312-1313.

Janick, J., J.N. Cummins, S.K. Brown, and M. Hemmat. 1996. Apples, p. 1-77. In: J. Janick and J.N. Moore (eds.). Fruit breeding. vol. 1. Tree and tropical fruits. John Wiley and Sons, New York.

Manganaris, A.G., F.H. Alston, N.F. Weeden, H.S Aldwinckle, H.L. Gustafson, and S.K. Brown. 1994. Isozyme locus Pmg-1 is tightly linked to a gene $\left(V_{f}\right)$ for scab resistance in apple. J. Amer. Soc. Hort. Sci. 119:1286-1288.

Novy, R.G. and N. Vorsa. 1996. Evidence for RAPD heteroduplex formation in cranberry: Implications for pedigree and genetic-relatedness studies and a source of co-dominant RAPD markers. Theor. Appl. Gen. 92: 840-849.

Sansavini, S., S. Tartarini, F. Gennari, and M. Barbieri. 2002. Scab (Venturia inaequalis) resistance in apple: the $V f$-gene and polygenic resistance in the breeding strategy at DCA-Bologna. Acta Hort. 595:29-32.

Tartarini, S. 1996. RAPD markers linked to the $V$ gene for scab resistance in apple. Theor. Appl. Genet. 92:803-910

Tartarini, S., L. Gianfranceschi, S. Sansavini, and C. Gessler. 1999. Development of reliable PCR markers for the selection of the $V_{f}$ gene conferring scab resistance in apple. Plant Breed. 118:183-186.

Xu, M., E. Huaracha, and S.S. Korban. 2001. Development of sequence-characterized amplified regions (SCARs) from amplified fragment length polymorphism (AFLP) markers tightly linked to the $V_{f}$ gene in apples. Genome 44:63-70.

Xu, M.L. and S.S. Korban. 2000. Saturation mapping of the apple scab resistance gene $V_{f}$ using AFLP markers. Theor. Appl. Genet. 101:844-851.

Table 2. Ratings of severity of fruit scab on fruiting seedlings in three apple populations. The 466-bp fragment is linked to $V_{f}$ whereas the 724-bp fragment is linked to $v_{f}$.

\begin{tabular}{|c|c|c|c|c|c|}
\hline \multirow[b]{2}{*}{ Population or genotype } & \multicolumn{5}{|c|}{ Fruit scab rating ${ }^{2}$} \\
\hline & 0 & 1 & 2 & 3 & Total \\
\hline \multicolumn{6}{|c|}{ A) 'GoldRush x 'Enterprise' } \\
\hline $466 / 466$ & 12 & 0 & 0 & 0 & 12 \\
\hline $466 / 724$ & 8 & 1 & 0 & 0 & 9 \\
\hline $724 / 724$ & 0 & 1 & 6 & 3 & 10 \\
\hline \multicolumn{6}{|c|}{ B) CQR10T17 x 'GoldRush' } \\
\hline $466 / 466$ & 4 & 0 & 0 & 0 & 4 \\
\hline $466 / 724$ & 12 & 0 & 0 & 0 & 12 \\
\hline $724 / 724$ & 1 & 1 & 2 & 2 & 6 \\
\hline \multicolumn{6}{|c|}{ C) 'Pristine' x 'GoldRush' } \\
\hline $466 / 466$ & 6 & 0 & 0 & 0 & 6 \\
\hline $466 / 724$ & 14 & 0 & 0 & 0 & 14 \\
\hline $724 / 724$ & 3 & 1 & 5 & 1 & 10 \\
\hline
\end{tabular}

${ }^{2}$ Ratings were 0 (no visible scab), $1=\leq 2$ lesions/tree, $2=3$ to 5 lesions/tree, or $3=\geq 5$ lesions/tree. 